\section{'Stump'}

A $\mathrm{S}$ regards modern developments of what is now widely alluded to as 'stump' planting, the method in all probability was first introduced to plant up now areas in connexion with the irrigated plantations in the Punjab plains, the species first utilized being the shisham (Dalbergia Sissoo). 'Stump' is really a misnomer; for the piece of the plant alluded to is a root and shoot or stem cutting. Its success and cheapness under certain conditions in the Punjab was striking, and this success has been repeated elsewhere in India, for example, in the Terai and Bhabar lands in the United Provinces, and in northern Nigeria in Africa with the same species.

But successful as has been the afforestation work with shisham stump planting, it has proved even more successful with teak in many parts of India, where artificial replanting or new afforestation work is being undertaken under certain types of condition. So valuable and cheap is the method that it has spread far beyond India, and interesting work has been obtained with stumps in the west coast and other forests of both British and French Colonies in Africa.

In the past there has been a good deal of controversy as to the best size (length and thickness) of the root and shoot cutting or 'stump'. An ordinary method of obtaining these for planting out purposes in both India and Africa is to sow seed in a nursery

\section{Planting}

and then root and shoot prune when one year old, leaving eight inches of root and one inch of stem. A. L. Griffith, the Madras sylviculturist, has now discussed an investigation into the best root length of stump to use when stump planting teak (Tectona Grandis) in areas having a general west coast type of climate (Ind. For. Rec., New Ser., 3, No. 1. Govt. of India Press, New Delhi, 1938).

From the details of the localities given it is obvious that by "west coast" the author moans the west coast of India and not the west coast of Africa. But the experiments here discussed will prove of equal use in the latter region, whero the introduction of stump planting is of a more recent date. The climate had an average annual rainfall varying from 60 in. to $120 \mathrm{in}$., and elevations varying from the plains at the foot of the Ghâts up to $3,000 \mathrm{ft}$. The soils at all centres wore light forest soils naturally well aerated. Briefly, Mr. Griffith carried out a series of experiments in different localities over a period of four successive years (1932-1935). His results may be summarized as follows: There are no appreciable differences in results, at the end of the first growing season after planting, from stumps within the root length range of 6 in. to 10 in. ; but a root length of 4 in. gives definitely poorer results. It was also demonstrated that stumps of $0.7-0.8 \mathrm{in}$. diameter give appreciably better results than those of $0 \cdot 3-0 \cdot 4 \mathrm{in}$. diameter.

\title{
Intelligence and $\mathrm{Birth}-\mathrm{R}$ ate
}

$\mathrm{I}^{\mathrm{N}}$ a paper entitled "Intelligence and Birth-Rate" read before the Industrial Soction of the British Psychological Society on February 8, Dr. L. S. Penrose summarized the present position regarding differential fertility and the docline in intelligence alleged to be taking place in Great Britain. By examining the results of differential birth-rates within the community, ho brings to light the trends of social selection that are taking place, and in doing so, he links together a number of facts not usually associated in considering these matters.

Although the general problems of a declining birthrate, owing largely to the efforts of the Population Investigation Committee, are beginning to attract wide attention, the effects of a differential fertility upon the ability of the nation as a whole are far too little appreciated. Knowledge of the relation between intelligence and birth-rate, as Dr. Penrose says, is of great practical importance in "planning the conditions of an efficient civilization". Even the most critical writors have been compelled to admit the prosence of some fall in national ability. Thus Prof. J. B. S. Haldane writes that we may "expect a slow decline perhaps of 1 or 2 per cent per generation in the moan intolligonce quotient of the country". ("Heredity and Politics", p. 117.)

The subject of a decline in the nation's intelligence is one that lends itself easily to sensationalism, and the presentation of Dr. Penrose is to bo welcomed as a dispassionate and timely one. At the outset he points out that the fall in the birth-rate may be due to diminution in family size, which implies a larger proportion of first-born children. Thus the average sibship in Great Britain now is said to be half of what it was fifty years ago.

Apparently, only in one type of mental defect, namely, that associated with lesions in the pyramidal tract, has Dr. Penrose been able to satisfy himsolf that primogeniture is a highly significant factor. But he admits the existence of evidence pointing to raised incidence, among the first-born, of abnormal confinements, still-births, and congenital malformations such as anencephaly, spina bifida and hydrocephalus. There is evidonce also that first-born children more frequently tend to becomo problem childron than the later born, though here other selective influences may bo at work bringing the firstborn children to the notice of the clinies. It has also been maintained that the first-born aro more likely to become insane than the later born, and that the chances of being convicted of criminality aro much greater in the first two members of a family than in the rest of the family.

Maternal age at the birth of a child is the next factor considered by Dr. Penrose. Where the birthrate is falling, the average maternal age will probably become greater. Dr. Penrose estimates the average maternal age in England as 29 years; in Japan it is said to be 26 yoars. Maternal age is particularly significant in tho etiology of mongolian imbecility, the chances of the occurrence of this kind of defoct being more than doubled for every increase of five years after the age of twenty-five years. The chances of the birth of a mongolian imbccile before the maternal 